\title{
PRESUPPOSITION, PERSUASION AND MAG FOOD ADVERTISING: A PRELIMINARY STUDY ${ }^{12}$
}

\author{
Tamara Bouso, Universidad de Santiago de Compostela \\ Email: tamara.bouso@rai.usc.es
}

\begin{abstract}
In this study presupposition is examined from the point of view of the type of information assumed by advertisers (Levinson 1983; Goddard 1998) and the functions they fulfil in achieving persuasion in nutritional advertising. Thus, 25 headlines from 5 health and fitness magazines (2012) have been classified according to the type of covert information. The results indicate that there are gender differences as regards this form of inferential information as well as the linguistic items that trigger these presuppositions. Whereas commercials addressed to men are more competitive, those addressed to women appeal more to their emotions.

Keywords: technical presupposition, ordinary presupposition, covert information, persuasion, magazine food advertising, gender differences, linguistic presuppositiontriggers.
\end{abstract}

Título en español: Presuposición y persuasión en los anuncios publicitarios de revistas de salud y fitness: un estudio preliminar

Resumen: Este trabajo examina la presuposición desde el punto de vista del tipo de información inferencial (Levinson 1983; Goddard 1998) y las funciones que esta desempeña en los anuncios publicitarios de revistas nutricionales. De este modo 25 encabezados extraídos de 5 revistas de salud y fitness (2012) se clasifican según el tipo de información asumida por el publicista (Hardin 2001). Los resultados indican que hay claras diferencias de género con respecto al uso de la presuposición así como de los elementos lingüísticos que dan lugar a estas presuposiciones. Mientras que los anuncios dirigidos a hombres son más competitivos, los orientados al sector femenino optan por la apelación de las emociones.

Palabras clave: presuposición técnica, presuposición ordinaria, información inferencial, persuasión, anuncios publicitarios, nutrición, diferencias de género, elementos lingüísticos presuposicionales.

\section{INTRODUCTION}

The well-known American advertising creative director Bill Bernbach (1911-1982) once said, “Advertising isn't a science. It's persuasion. And persuasion is an art”. It is very likely

\footnotetext{
1 Date of reception: 31 May 2012

Date of acceptance: 30 October 2012

2 For generous financial support, I am grateful to the European Regional Development Fund and the Autonomous Government of Galicia (Directorate General for Scientific and Technological Promotion, grant CN2012/012).
} 
that Bernbach was not alluding here to public service advertisements (aka announcements) but to commercial consumer advertising, given that one of the main goals of this type of advertising, if not the most important one, is persuading or manipulating people's minds in order to sell a product. Leech defines it as follows, "advertising directed towards a mass audience with the aim of promoting sales of a commercial product or service" (1966: 25). Robin Lakoff described persuasive discourse as the "attempt or intention of one participant to change the behavior, feelings, intentions, or viewpoint of another by communicative means" (1982: 28). But how is persuasion achieved? What are the strategies that govern persuasive discourse, and more specifically, the persuasive discourse of advertising?

Karol Hardin stated that violation of Grice's Maxims is a key pragmatic strategy in effecting persuasion because these allow "the advertiser or speaker in an ad to communicate more than what is actually said" (2001: 47 \& 212; emphasis mine). Along with Gricean Maxims' violations, ${ }^{3}$ presupposition is also a very frequent strategy exploited in the language of advertising. The word 'presupposition' comes from the verb 'presuppose' which means "to assume, suppose or postulate beforehand; to take for granted" (O.E.D s.v. presuppose, $v$. 1.a). Thus, similarly to the maxim's violations, presuppositions also refer to some additional meaning that is not explicitly stated but which is communicated.

Closely connected to these two types of inferential communication are the so-called conventional and conversational implicatures. While conventional implicatures are directly related to presuppositions, ${ }^{4}$ conversational implicatures are the result of violations of Grice's Maxims. Unlike conventional implicatures, which mainly derive from the grammar or lexical items of an utterance, conversational implicatures require the audience to work out their meaning and consequently, their interpretation may differ from one individual to another. Finally, it is worth mentioning in this introductory section that both presuppositions and Grice's Maxims violations are two types of covert communication commonly used in advertising for mainly two reasons. Firstly, they try to make the addressee forget that the speaker is trying to sell the reader something; and secondly, they help the speaker to "avoid taking responsibility for the social consequences of certain implications arising from advertisements" (Tanaka, 1994: 44).

The present study focuses on the role of presupposition in magazine food advertising. Firstly, I briefly explain what is understood in the literature by presupposition, and then I classify a sample of advertisements according to the type of information that is presupposed, devoting special attention to the linguistic structure of the sentences that give rise to technical presuppositions. Finally, in the light of the results of my analysis, an account of the pragmatic functions of presuppositions in English magazine advertising is provided, focusing this time on their persuasive function.

\footnotetext{
See Pop (2010) for a recent analysis of maxim flouting in English and Romanian print advertising.

4 Karttunen and Peters (1979) explain that there is no sharp distinction between presuppositions and conventional implicatures. What distinguishes conventional implicatures from other types of presuppositions is that presuppositions are often less cancellable than convencional implicatures.
} 


\section{THEORETICAL FRAMEWORK: TECHNICAL (SEMANTIC?) AND CONVENTIO- NAL (PRAGMATIC?) SENSE OF THE PHENOMENON}

According to Levinson, two senses of the word 'presupposition' have been distinguished within the field of linguistics: a technical and a more conventional side of the phenomenon. Despite this two-fold distinction, however, there is no total agreement among theorists as regards the definition of the technical sense of presupposition. Levinson explains the following,

(...) there is more literature on presupposition than on almost any other topic in pragmatics (excepting perhaps speech acts), and while much of this is of a technical and complex kind, a great deal is also obsolete and sterile (1983: 167; emphasis mine).

George Yule (1996), for example, approaches the technical sense of the word in relation to entailments. He asserted that in conversations speakers may assume certain information already known by their listeners. Given that this information is treated as known, the speaker will not explicitly express this information and will count as part of what is communicated but not stated. Thus, he distinguishes two types of known communication: presuppositions and entailments. In Yule's words, their difference relies on the fact that "speakers, not sentences, have presuppositions" and "sentences, not speakers, have entailments" (1996: 25). Another commonly mentioned feature of presuppositions that differentiates them from entailments is their constancy under negation. This means "the presupposition of a statement will remain constant (i.e. still true) even when that statement is negated" (Yule, 1996: 26). While negation alters a sentence's entailment, its presupposition always remains untouched. Examples (1), (2) and (3) below confirm these premises:

\section{(1)}

a. Everybody knows that John is gay. $(=p)$

b. Everybody doesn't know that John is gay. (= NOT p)

c. John is gay. $(=q)$

d. $\quad \mathrm{p}>>^{5} \mathrm{q} \&$ NOT $\mathrm{p}>>\mathrm{q}$

(Yule, 1996: 27)

(2)

a. "I used to think it was my fault that Windows didn't work properly". ${ }^{6}(=\mathrm{p})$

b. I used to think it wasn't my fault that Windows didn't work properly. (NOT

p)

c. Windows didn’t work properly. $(=\mathrm{q})$

d. $\quad \mathrm{p} \gg>\mathrm{q} \&$ NOT $\mathrm{p}>\mathrm{q}$

(3)

a. John managed to stop in time. $(=p)$

b. John didn't manage to stop in time. (NOT $\mathrm{p}$ )

c. John stopped in time. $(=\mathrm{q})$

\footnotetext{
The symbol $>>$ stands for 'presupposes'.

6 Example taken from this website: $<$ http://www.stanford.edu/class/linguist34/Unit_02/presupposition.htm $>$
} 


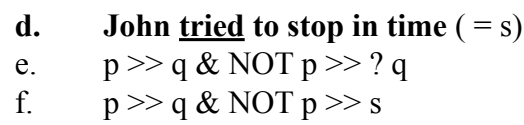

In this last example, one should notice that (3d) is a presupposition of both (3a) and (3b). However, although (3a) entails (3c), (3b) does not entail (3c).

By way of summary, both Levinson and Yule seem to attend to the concept of entailment from a semantic perspective: "A semantically entails B (...) iff every situation makes A true, makes B true (or: in all worlds in which A is true, B is true)" (Levinson, 1983: 174).

Now, I will turn my attention to what is understood by the conventional sense of the linguistic phenomenon of presupposition. As mentioned above, Levinson in his book Pragmatics (1983) makes reference to the two senses of the word presupposition, explaining that the ordinary or conventional sense of presupposition refers to "any kind of background assumption against which an action, theory, expression or utterance makes sense or is rational" (1983: 168; emphasis mine). Some clear examples Levinson provides are:

- Effects presuppose causes

- John wrote Harry a letter, presupposing he could read

- Harry asked Bill to close the door, presupposing that Bill had left it open as usual; he hadn't so he threw a chair at Harry

- Adolph addressed the butler as "sir", presupposing that he was the host Sir Ansel himself

- The theory of evolution presupposes a vast time-scale

(Levinson, 1983: 168)

Levinson asserts that the main difference between the ordinary and the technical sense of presupposition is the fact that the latter is "restricted to certain pragmatic inferences or assumptions that seem at least to be built into linguistic expressions and which can be isolated using specific linguistic tests (especially, traditionally, constancy under negation (...)" (1983: 168; emphasis mine).

Finally, it is worth mentioning that these two senses of the word presupposition seem to me to correspond to the 1970s distinction between the semantic and the pragmatic notions of presupposition (See Stalnaker 1972, 1974; Katz \& Langendoen 1976). However, as Peter Grundy claims, "this distinction may be problematic" (2008: 49). Also, Levinson emphasises the controversial nature of this two-fold distinction,

But from 1973 onwards it became increasingly clear that there were so many problems with the notion of semantic presupposition that a theory of language (and specially of semantics) would do better without it (1983: 177).

In the light of these basic notions on the phenomenon of presupposition, the main aim of the present study is to find answers to the following questions: 
- To what extent does magazine food advertising make use of presuppositions?

- What type of information is taken for granted in nutritional advertisements? Are there any gender differences?

- When it comes to conventional presuppositions, what linguistic presuppositiontriggers are the most frequently used by nutritional advertisers?

- And finally, what functions does the linguistic phenomenon of presupposition serve in advertising?

\section{METHODOLOGY AND MATERIALS}

In order to answer all these interrogatives, I compiled a corpus of 52 nutritional ads of half of a page and one page from 5 health and fitness sports magazines of three different types: Women's Health magazine (January/February 2011), Health and Fitness (March and April 2012) and Men's Health magazine (March and April 2012). All the magazines come from the UK except Women's Health magazine, which is American. Moreover, they have been chosen for their comparability in terms of genre (health and fitness sports magazine), age of the audience (between 18 and 35 years old) and topic (health and fitness). While Women's Health and Health and Fitness are addressed to women, Men's Health as the very title indicates is addressed to men. It is noteworthy that this choice has not been made at random but in order to explore possible gender differences as regards the role of presupposition in nutritional advertising. As Figure 1 illustrates, whereas men seem to be more concerned with muscle building products and sports supplements (white boxes), women are more keen on buying dietary supplements, chocolate bars, almonds and other kind of products (grey boxes).

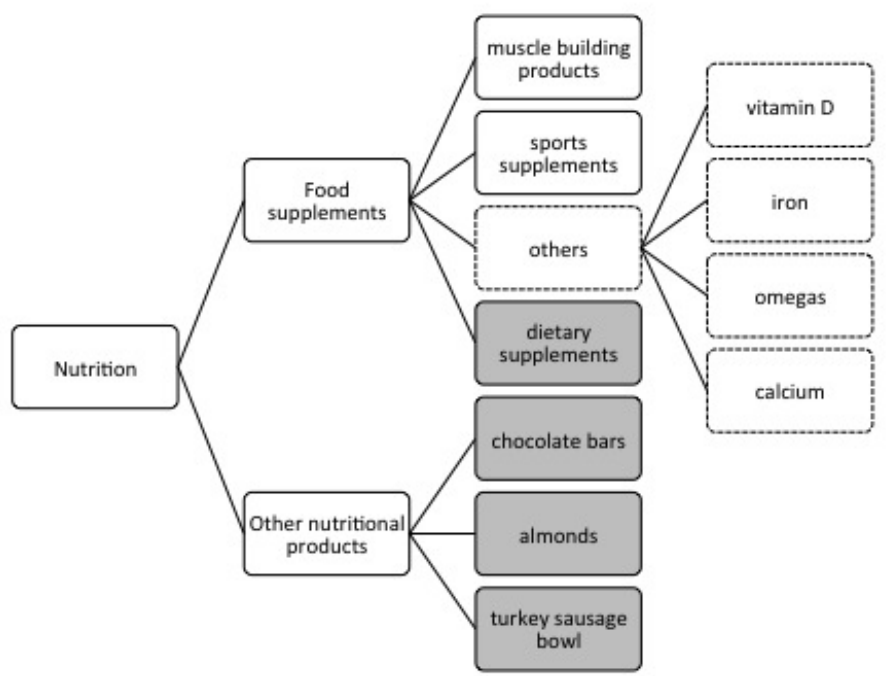

Fig. 1. Nutritional advertisements according to type and gender (dotted line box: ads addressed to both men and women; grey box: ads only addressed to women). 
The corpus of 52 nutritional advertisements is more or less equally distributed across the selected magazines with a mean of $10^{7}$ advertisements per magazine as illustrated in Figure 2. Finally, it is worth noting that only commercial consumer advertising has been taken into account whereas public service advertisements have been discarded.

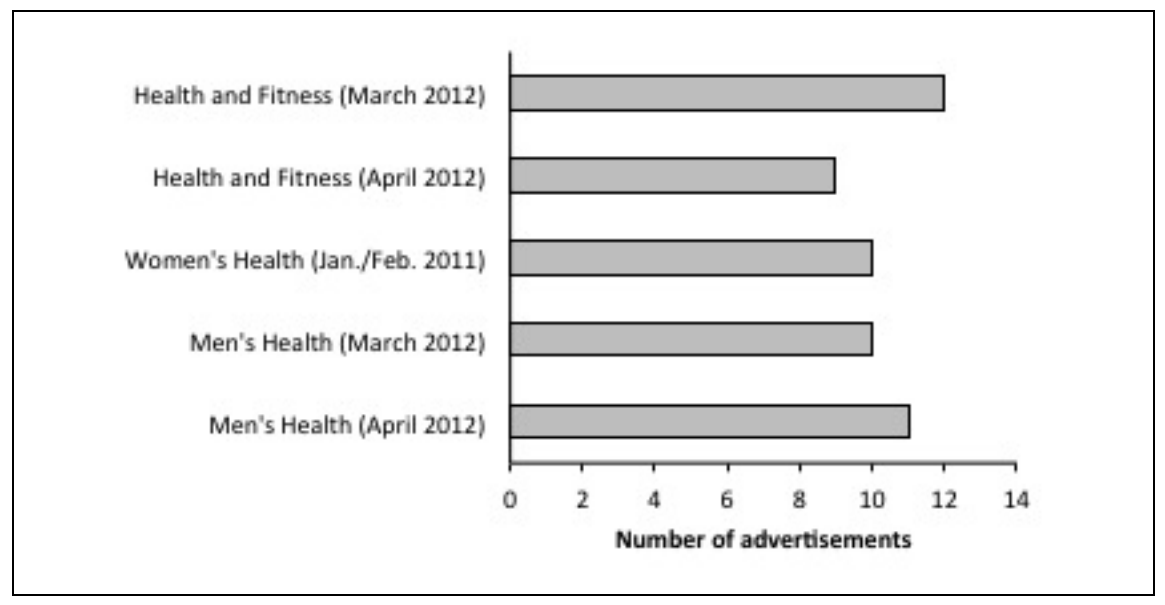

Fig. 2. Corpus of nutritional advertisements distributed across magazines.

\section{RESULTS AND DISCUSSION}

\subsection{The role of presupposition in Magazine Food Advertising: presupposed information}

Presuppositions are important in advertising because they allow advertisers to engage in a fictional conversational exchange with their audience by taking certain information for granted. After analysing the headlines and sub-headlines ${ }^{8}$ of the advertisements from the magazines selected for this study, the findings indicate that presupposition is a highly frequent strategy in magazine nutritional advertisements. In the 52 advertisements collected for this project, there were 12 repeated nutritional ads ${ }^{9}$ making a total of 40 different commercials, out of which, instances of presuppositions were found in $25^{10}$ :

\footnotetext{
7 Interesting enough is the fact that there are no nutritional advertisements in the Spanish version of Men's Health. Perhaps this indicates that male Spaniards do not rely so heavily on this type of products.

8 Other components of the advertisements (the slogan, the body copy, the visualization, the layout and the trademark) have been ignored because they go beyond the scope of this preliminary study of presuppositions. The headline and the sub-headline have been chosen because the former is the most read part of an advertisement and the latter complements in a way the message conveyed in the headline. The subheading elaborates the headline or stresses the unique features of a particular product. For further information concerning this, see $<$ http://www.mbaknol.com/marketing-management/the-components-of-an-advertisement/.

9 See Appendix II (repeated ads are underlined)

10 See Appendix I
} 


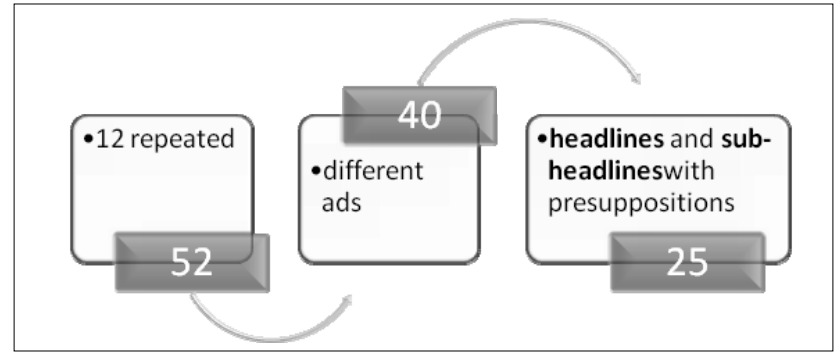

Fig. 3. Findings.

In what follows, the 25 headlines (and sub-headlines) presenting the linguistic phenomenon of presupposition are classified into six groups according to the type of information assumed by the advertiser (see Table 1 below). Also, as previously mentioned, special attention is paid to the different linguistic items that generate these presuppositions. For this task, I take as main points of reference Hardin's taxonomy of presuppositions elaborated in her study Pragmatics in Persuasive Discourse of Spanish Television Advertising (2001); and Levinson's Pragmatics (1983: 181-185) in which he provides an exhaustive list of presupposition-triggers, more specifically, of constructions that have been considered by important linguists as sources of presuppositions (Strawson 1950, 1952; Karttunen 1971; Kiparsky \& Kiparsky 1971 among others)

Table 1. Hardin's taxonomy of presuppositions.

\begin{tabular}{|l|}
\hline Presupposed audience's habits and activities \\
\hline Presupposed audience's desire for change \\
\hline Presupposed audience's possessions \\
\hline Presupposed audience's feelings, needs, actions and aspirations \\
\hline Presupposed audience's reactions \\
\hline Presupposed uniqueness, superiority and improvement of a product \\
\hline
\end{tabular}

\section{Presupposed audience's habits and activities}

In this first group of presuppositions, the speaker presupposes that the audience has certain habits or has not been initiated in certain types of activities. E.g.:

1. Your daily dose of sunshine... guaranteed

2. YOUR 12-WEEK NEW BODY STARTER PACK

Both headlines contain technical presuppositions triggered by a series of linguistic items (the possessive determiner your and the lexical items daily, new and starter). As expected in technical presuppositions, these remain constant under negation (Your daily dose of sunshine is NOT... guaranteed; (This is NOT) your 12-week new body starter pack). Also, 
if we read between lines, we will be able to notice a great array of ordinary presuppositions the audience process without consciously paying attention to them.

As Angela Goddard points out in her book The Language of Advertising (1998), presuppositions play a very important role in the Economy Principle of Languages, and certainly, without presuppositions "utterances would be very uneconomic" (1998: 125). She provides the following example asked of someone in a pub:

- Have you got a light, please?

Some of the presuppositions this question contains are:

- That 'light' is understood as match

- That the 'light' has not run out of fuel

- That the person will do more than just answering to the question

If the speaker did not make use of presuppositions, he or she would not be attending to the Economy Principle of Languages yielding to everlasting tedious conversations, such as the following:

Are you in possession of a box of matches or cigarette lighter, please, and, if you are, are they in working order, and would you be willing to allow me to use either of them, and could you therefore indicate that willingness or otherwise by responding?

(Goddard, 1998: 52)

Now if we focus on the two first headlines under examination, we observe that these also contain several presuppositions. Some of these are:

$>$ (DLUX 1000 is/is NOT) Your daily dose of sunshine ...

$>\quad$ Sunshine comes in doses

$\gg \quad$ Sunshine daily is required for good health

$\gg \quad$ Sunshine daily doses are available in purchasable form

$>\quad$ Sunshine in England does not provide people with their daily needed dose of vitamin D

> The reader has the habit of taking a dose of sunshine daily

$>\quad$ (USN is/is NOT) YOUR 12-WEEK NEW BODY STARTER PACK

>> Starter packs with essential products help people initiate the process of a new body

> In just a matter of twelve weeks one can successfully begin the process of a new body with the help of a starter pack

$>\quad$ The readers have no idea how much work will be required beyond the star$\operatorname{ter}^{11}$

> The readers have not been initiated in this 12-week bodybuilding transformation

\footnotetext{
$\overline{11}$ It seems to me that the words 12 -week and starter are in a way contradictory in this highly nominalised
} headline. 
If the advertiser did not take certain information for granted, the same message could only be conveyed in a long-winded way. Moreover, in the commercials under examination, we can observe how the assumed information by the advertisers in the headline is further elaborated in the body copy of the ad.

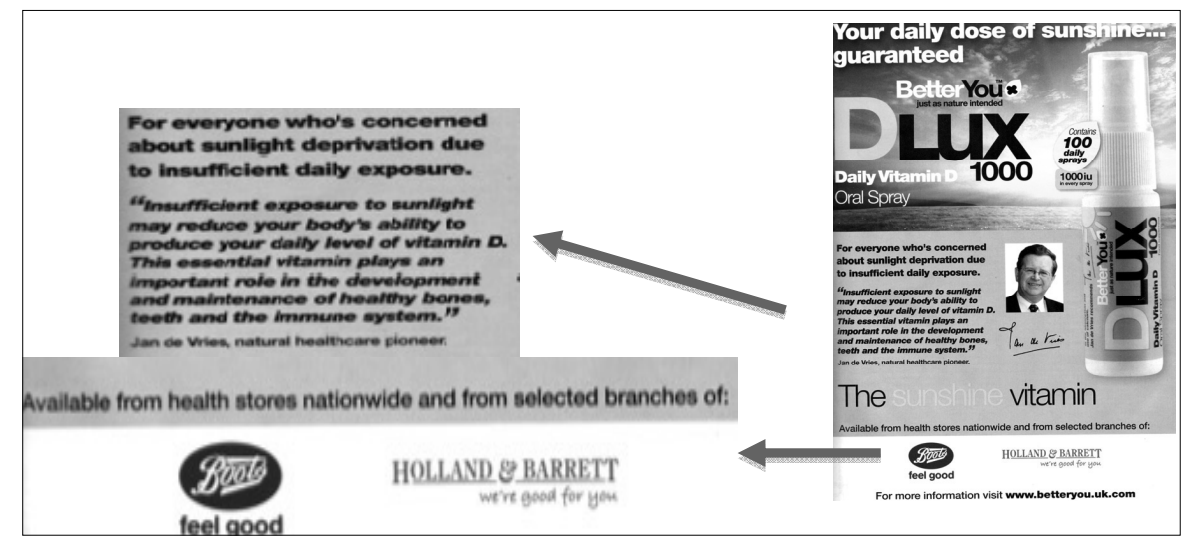

Fig. 4. DLUX 1000.

Your daily dose of sunshine...

> Sunshine comes in doses

- Sunshine $=$ vitamin D

$>$ Sunshine daily is required for good health

- Daily level of vitamin D plays an important role in the development and maintenance of healthy bones

>>Sunshine daily doses are available in purchasable form

- Available from health stores nationwide and from selected branches of Boots, and Holland \& Barret

(USN is/is NOT) YOUR 12-WEEK NEW BODY STARTER PACK

>> Starter packs with essential products help people initiate their process of a new body

The ultimate starter pack with the essential products to start your 12-week body transformation

$>\quad$ In just a matter of twelve weeks one can successfully begin the process of a new body with the help of a starter pack

Transform your body in 12 weeks 
$>\quad$ The readers have no idea how much work will be required beyond the starter

The pack will only help the readers begin the process of a new body (hence its name "starter pack"). Thus the advertisement as a whole is misleading because the picture that it shows does not go in accordance with what the headline actually says. If this is a starter pack, is it possible for a normal person who is a little overweight to look like a powerfully built muscle bound person in just a matter of 12 weeks?

> The readers have not been initiated in this 12-week bodybuilding transformation

Take your Before photo...

(...) When will you start your transformation?

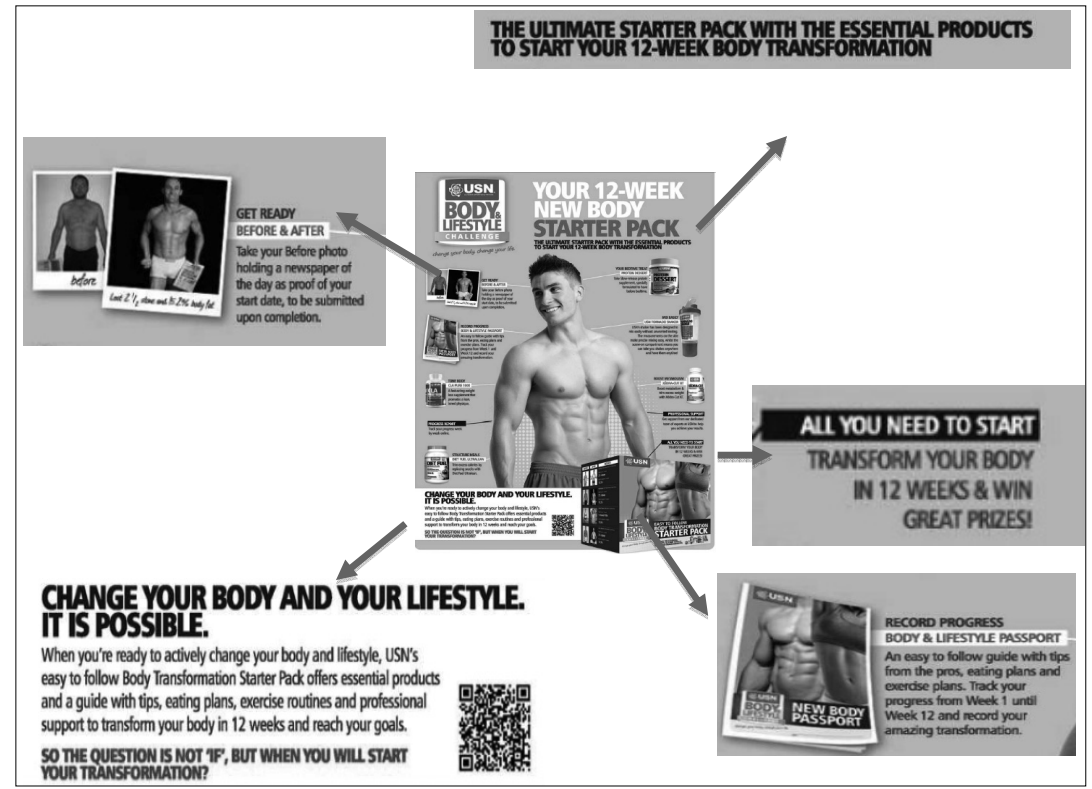

Fig. 5. USN (Ultimate Sports Nutrition).

\section{Presupposed audience's desire for change}

Other presuppositions have to do with the audience's desire for change $\mathbf{~}^{\mathbf{1 2}}$, in such cases the speaker assumes the audience would like to change to something apparently better. The examples below illustrate this idea,

3. (Take these diet proteins and/to) CHANGE your reflection

\footnotetext{
12 Hardin provides the following example: Juega y cambia tu vida (Play and change your life, Lotería Primitiva, SPAIN) (2001: 88).
} 
4. (Take this and/to) Get NOTICED!

5. Do you want to know The Secrets of Slimming?

These headlines contain the following presuppositions: (a) 'You're looking a bit fat', (b) you are not happy with this situation and therefore, (c) you wish to change that. In examples (3.) and (4.), these presuppositions are triggered by the presence of change-of-state verbs (get and change) and the possessive determiner your, whereas in (5.), the source of some of these presuppositions is the presence of the definite article the.

(4)

- (Take these diet proteins to) change your reflection

- (Don't take these diet proteins to) change your reflection

- $\quad>$ You don't look good

(5)

- (Take this to) get noticed!

- (Don't take this to) get noticed!

- $\quad>>$ You are not being noticed because you are not thin

(6)

- Do you want to know the secrets of slimming?

- Don't you want to know the secrets of slimming?

- $\quad$ > You are a bit overweight

Finally, it is worth mentioning that in these three examples we can clearly observe the euphemistic function of the linguistic phenomenon of presupposition. In all cases analysed, the speaker seeks to avoid directly telling the readers that they are a bit fat because this idea would threaten their face and consequently, make them feel uncomfortable with the fictional linguistic exchange created in the headline.

\section{Presupposed audience's possessions}

There are also a couple of examples in the corpus in which the speaker takes the existence of certain objects or products for granted. In example (6.), we observe that a link is created between these objects the audience presumably possesses and the product being advertised. On the other hand, in example (7.), this type of presupposed information is used to establish an implicit competition with products of other brands and encourage the audience to own the product being advertised.

\section{6. (Do you....) LITTLE BLACK DRESS? / NEW YEAR? / THAT $^{13}$ BEACH BIKINI?}

7. Does your cereal measure up?

Example (6.) is a question that in ordinary conversation would be expressed in a very different way. One possibility could be the following: Do you want to wear the/that little

\footnotetext{
13 It is noteworthy that the demonstrative adjective that presupposes that the audience has more than one bikini. Thus, that could also be considered a linguistic presupposition-trigger in this case.
} 
black dress on New Year's Eve? Do you expect to fit into that beach bikini in the New Year? Although part of the question has been elided in the headline of the advertisement for conciseness purposes, readers are able to unconsciously reconstruct in their minds the missing parts of the sentence. As expected, the main presupposition in both the short and the longer version of the headline, remains the same as (7) illustrates.

(7)

a. Do you want to wear the/that little black dress on New Year's Eve?

b. $\quad$ Do you expect to fit into that beach bikini in the New Year?

c. Don't you want to wear a little black dress on New Year's Eve?

d. Don't you expect to fit into that bikini in the New Year?

e. $\quad>>$ The reader (supposedly) has a little black dress and a beach bikini

Certainly, part of the effectiveness of this headline relies on the link created between these presupposed objects and the product advertised. The overall layout of the advertisement seems to suggest that if the readers provide a positive answer to the questions presented in the headline, then it is highly recommendable that they take those slimming pills that will help them fulfil their desires, i.e., wear their little black dress on New Year's Eve and their beach bikini in the coming year.

In example (7.), the speaker once again poses a question, this time presupposing that the audience has cereal (8). In this case, the advertisement suggests that the cereal being advertised contains as much proteins as an egg, and that it is very likely that the audience's brand of cereal does not present this quality.

(8)

a. Does your cereal measure up?

b. Doesn't your cereal measure up?

c. $\quad>>$ The reader has cereal

d. $\quad>>$ The reader presumably eats a particular brand of cereal different from the one being advertised.

\section{Presupposed audience's needs, aspirations and actions}

Most times, the speaker presupposes certain needs (food for the whole body, omegas, vitamin D), actions (perform some sort of action) and aspirations (greater muscles, to be faster, stronger and for longer, to burn more fat). Some of these examples stand out for their ordinary/conventional presuppositions (8. and 9.) that only make sense if the reader has certain knowledge of the world. Example (8.) suggests that Sun Chlorella A is a complete supplement that provides the body with all the food it needs, whereas example (9.) implies that women will have a better health if they take Paradox's omega oil. It is worth mentioning that neither of them would be rational if the readers did not know that the human body needs vital nutrients that make it function or that omegas play an important role to maintain the health and the well being of women throughout their life-time.

8. (Sun Chlorella A is) Whole food for your whole body

9. We take care of our omegas / you take care of your health 
Other headlines, however, are mainly characterised by the technical sense of this linguistic phenomenon being triggered by certain linguistic elements: $W H$ - questions (11.), comparatives (13., 14., 15.) definite descriptions (12.), factive expressions such as "Chances are"/"it is very likely that", e.g.: 10.) and lexical items (enough in 10.). Thus, the following headlines could be analysed as follows:

10. Chances are (aren't), (that) you're not getting enough vitamin D $>$ The readers get some vitamin D

11. WHAT (doesn't) DRIVES YOU? >> There is something that drives you; readers perform some actions

12. THE TEAM BEHIND THE TEAM / maximuscle (is/is not) BEHIND YOUR PERFORMANCE

$>$ Readers perform some sort of action

13. (OMNI promotes/doesn't promote) GREATER MUSCLE GAINS THAN ANY OTHER PRODUCT

>> There are other products that also promote muscle growth

14. (With Lucozade you will go) FASTER. STRONGER. FOR LONGER ${ }^{14}$ (than with water)

>> Readers take water when they practise some sport

15. (You will) Burn $41 \%$ More Fat During Exercise (than with normal carbohydrate sports drink)

>> Readers take carbohydrate sports drink to burn fat during exercise

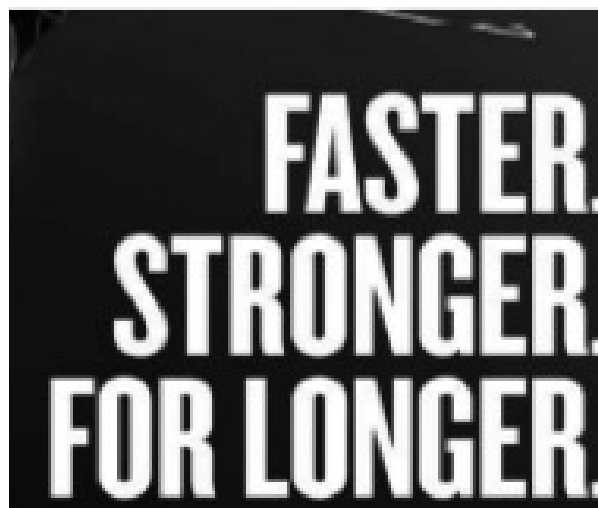

At the limits of your sporting ability

it's important to hydrate fast. Water

can only take you so far, so you need

a fuel that can sustain performance

Lucozade Sport is an isotonic drink

that enntains alnetrolytes to replaniah

nutrients your body loses in sweat

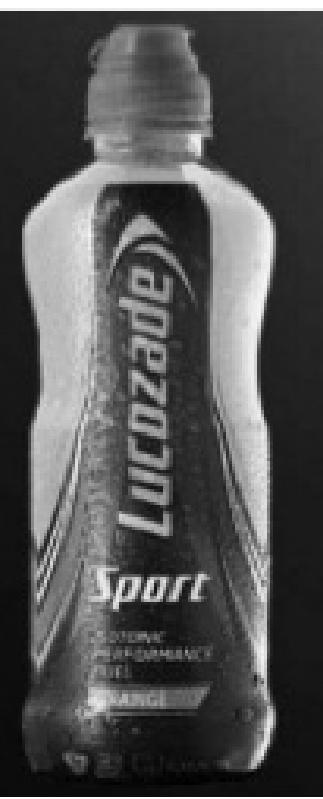

Fig. 6. Lucozade Sport.

14 This advertisement appears thrice in the corpus compiled for this project (Health and Fitness, March 2012; Men's Health, March 2012; Men's Health, April 2012). 
Independent Research:

Simply drinking Low Calorie ZERO instead of a normal carbohydrate sports drink, 22 participants burned on average $41 \%$ more fat during exereise.

Fig. 7. Low Calorie ZERO.

\section{Presupposed audience's expressions of doubt or surprise:}

Sometimes the speaker takes doubts or reactions by the audience for granted, clearly elicited by the images of the advertisement. What advertisers do in these cases is to create a pseudo-dialogue between the speaker and the viewer:

16. yes, Really

>> The readers think that Weight Watchers Yogurt tastes amazing

17. Definitely

>> The readers think that Weight Watchers Coffee Cake tastes as good as it looks

It's creamy and full of delectable apple pie flavor.

It has a lower Points Plus" value than some light yogurts.

And yes, the new taste of Weight Watchers Yogurt" is really amazing.

Fig. 8. WeightWatchers' Apple Pie a la Mode.

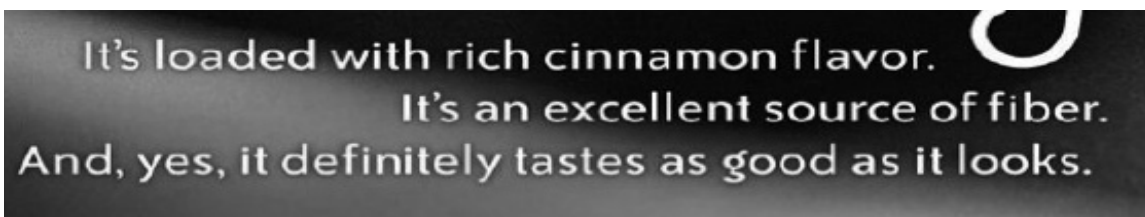

Fig. 9. WeightWatchers' Coffee Cake.

\section{Presupposed uniqueness, improvement and superiority of a product establishing} in most cases an implicit competition

In this last group, the speaker presupposes the improvement of a product (especially by means of the lexical item new), or the superiority of the advertised product in relation to other similar items on the market, an idea that is mainly conveyed through the use of comparatives and superlatives. Although the headlines included in this group are direct and assertive, these are also characterised by their inexactness or lack of precision, a feature that allows advertisers to defend the veracity of their claims. Notice, for example, headline (21.) in which the adverbial probably mitigates the assertion of the headline. 
18. (Health Spark's African Mango is) "The New Superfood Weight Loss Sensation" / (Health Spark's African Mango is) The UK's Highest Strength \& Best Quality African Mango

>> There are different types of superfoods that aid people to lose weight

$>$ There are several brands of African mango

$>$ There is a gradation of quality

Entailment: There is no better brand of African Mango in the UK than Health Spark's African Mango

Note: in this case the lexical item new does not presupposes an improvement of the product itself, it just indicates Health Spark's African Mango is the latest superfood on the market ${ }^{15}$ (cf. 24.).

19. THE BEST JUST GOT BETTER

$\gg$ There are several sports nutrition products

$>>$ There is a gradation of quality

Entailment: The formula of PhD's Synergy ISO-7 has been improved

20. Best-in-Class Fish Oils

$>>$ There are several fish oils

$>$ There is a gradation of quality

Entailment: None of them is better than GNC's fish oil

21. Probably the BEST muscle-gain shake in the world/Maximum gains in muscle

size \& strength - guaranteed.

$>>$ There are several muscle-gain shakes in the world

$>$ There is a gradation of quality

22. CHANGE / TO A SUPERIOR PROTEIN

$>\quad$ There are other proteins

$>\quad$ The readers are taking inferior proteins

23. (New Caltrate Soft Chews have) $\mathbf{2 0 \%}$ more calciyum (than Viactiv)

$>$ There are chews that contain calcium

$>$ Some chews have more calcium than others

24. New ${ }^{16}$ Platinum Hydro Builder

>> There have been other Platinum Hydro Builder's proteins before

>> Platinum Hydro Builder has been improved

25. (CELSIUS is) The Fastest Growing Pre-Exercise Drink in America!

$>$ There are other pre-exercise drinks in America

$>$ There is a gradation of quality

Entailment: there is no faster pre-exercise drink in America than CELSIUS

It is worth mentioning here that although the 25 headlines have been classified according to the main type of information presupposed by the advertiser, this does not imply that other presuppositions cannot be inferred from these headlines; quite the contrary, most

\footnotetext{
15 Some definitions the O.E.D. provides for the term "new" are:

a. Not previously existing; now made or brought into existence for the first time (cf. 19.)

b. Additional to that which was present before; further, renewed. (cf. 25.)

16 Others tend to include this presupposed improvement of the product in the trademark New Vitabiotics Wellman Optimuscle or in a sub-headline The Ultimate Pre Workout Cell Voluminizing \& Focus Formula.
} 
headlines contain several presuppositions (ordinary and technical) as we have explicitly seen in (1.) and (2.).

\subsection{The role of presupposition in Magazine Food Advertising: gender differences}

As previously mentioned, one of the main aims of this project is to explore possible gender differences regarding the type of information taken for granted in the headlines of magazine food advertising; Tables $\mathbf{2}$ and $\mathbf{3}$ below illustrate some of these differences. Table 3 shows that commercials addressed to men seem to be more competitive, assuming that the product advertised is unique and superior to any other similar product on the market. On the other hand, when creating commercials addressed to women advertisers seem to strategically appeal to women's needs and aspirations in order to catch their attention and sell the advertised product.

Table 2. Type of presupposition and gender differences (all magazines included) ${ }^{17}$.

\begin{tabular}{|l|l|l|l|}
\hline Code & Type of presupposition & Women & Men \\
\hline A & Habits and activities & 1 & 1 \\
\hline B & Desire for change & 3 & 0 \\
\hline C & Audience's possessions & 2 & 0 \\
\hline D & Needs, actions and aspirations & 5 & 3 \\
\hline E & Reactions & 2 & 0 \\
\hline F & Uniqueness and improvement of a product & 4 & 4 \\
\hline
\end{tabular}

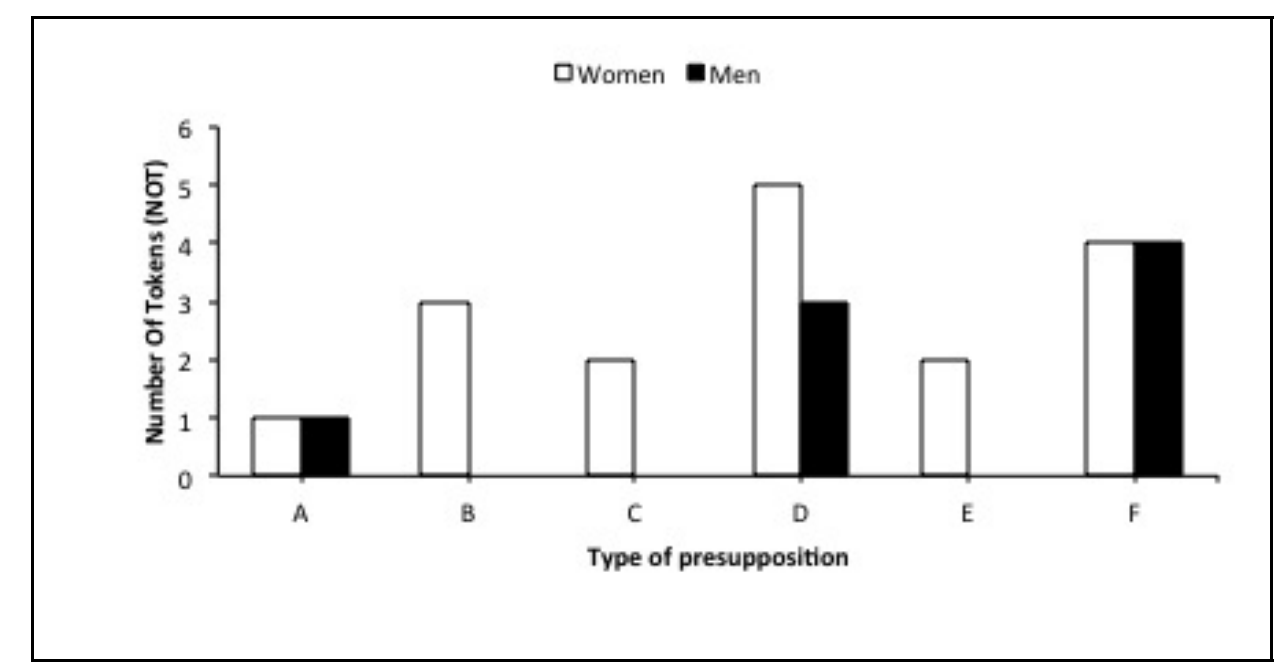

Fig. 10. Type of presupposition and gender differences (all magazines included).

17 Table 2 includes all the magazines, whereas in Table 3, Women's Health magazine (the American one) has been discarded in order to make a more valid comparison with more or less the same number of ads addressed to men and women. 
Table 3. Type of presupposition and gender differences (excluding Women's Health magazine).

\begin{tabular}{|l|l|l|l|}
\hline Code & Type of presupposition & Women & Men \\
\hline A & Habits and activities & 1 & 1 \\
\hline B & Desire for change & 3 & 0 \\
\hline C & Audience's possessions & 1 & 0 \\
\hline D & Needs, actions and aspirations & 4 & 3 \\
\hline E & Reactions & 0 & 0 \\
\hline F & Uniqueness and improvement of a product & 1 & 4 \\
\hline
\end{tabular}

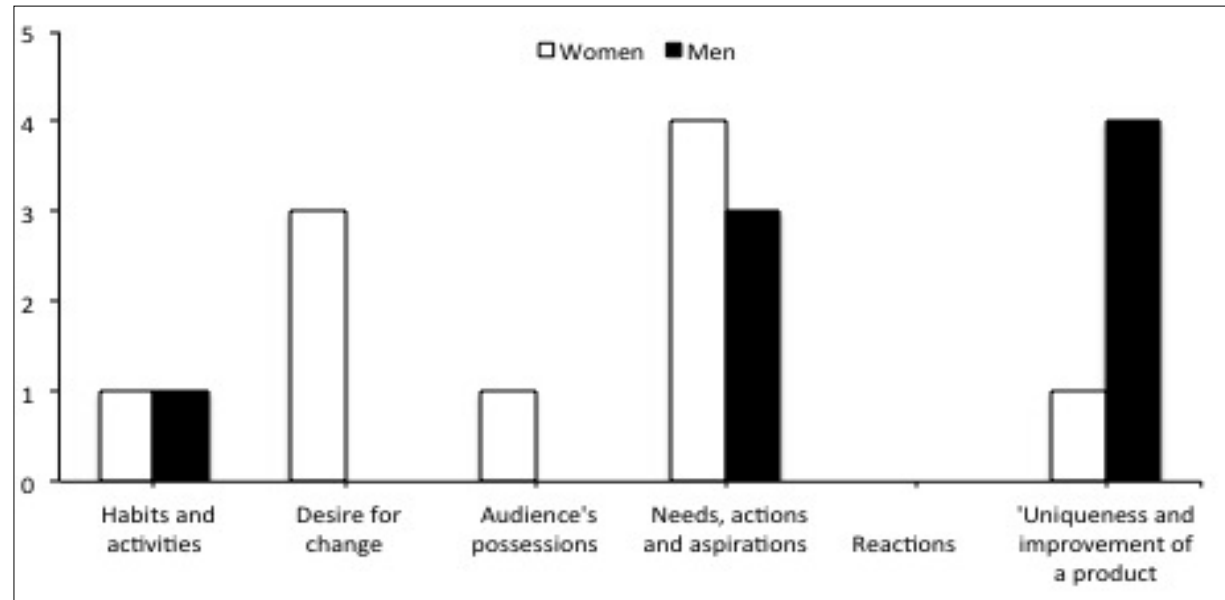

Fig. 11. Type of presupposition and gender differences (excluding Women's Health magazine).

\subsection{The role of presupposition in Magazine Food Advertising: presupposition- triggers}

Taking into account the results shown in 4.2, it is no surprising that the linguistic presupposition-triggers most frequently used by nutritional advertisers be comparative constructions, definite descriptions and change-of-state verbs, as represented in Figure 12 below. 


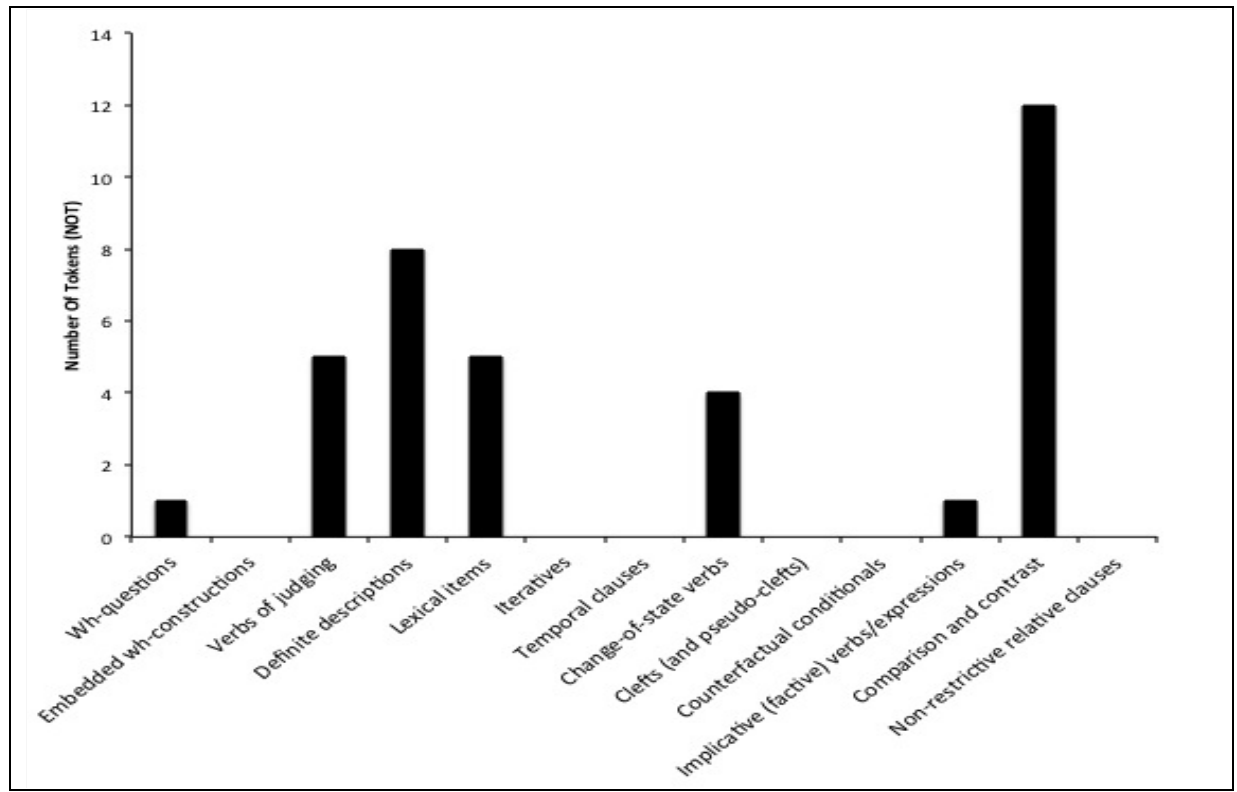

Fig. 12. Linguistic presupposition-triggers.

\subsection{The AIDMA Law and the role of presupposition in consumption behaviour}

As it has been previously shown, part of the success of an advertisement relies on the type of information that is taken for granted. This presupposed information helps to create a link between a product and its potential consumers by drawing their attention, their interest and their desire for a particular product. In the following lines, I will explain the three different stages consumption behaviour goes through, focusing not only on the role of presupposition but also on other aspects that may have an influence on the consumer for the purchase of the advertised product.

Roland Hall came up with a hypothesis called the AIDMA LAW ${ }^{18}$ to explain consumption behaviour. This hypothesis describes the process of consumption from that moment when a consumer finds out about a given product up to that stage in which the consumer buys and uses such product. This process is divided into three stages: a Cognition Stage, which represents the first contact of the consumer with the product, an Affect Stage in which the consumer becomes interested in the product, wants the product and remembers it. And a third stage, called the Action Stage, in which the consumer finally purchases and uses the product. These three stages appear represented in Figure 13.

18 Retrieved from: $<$ http://www.mitsue.co.jp/english/case/marketing/02.html $>$ 


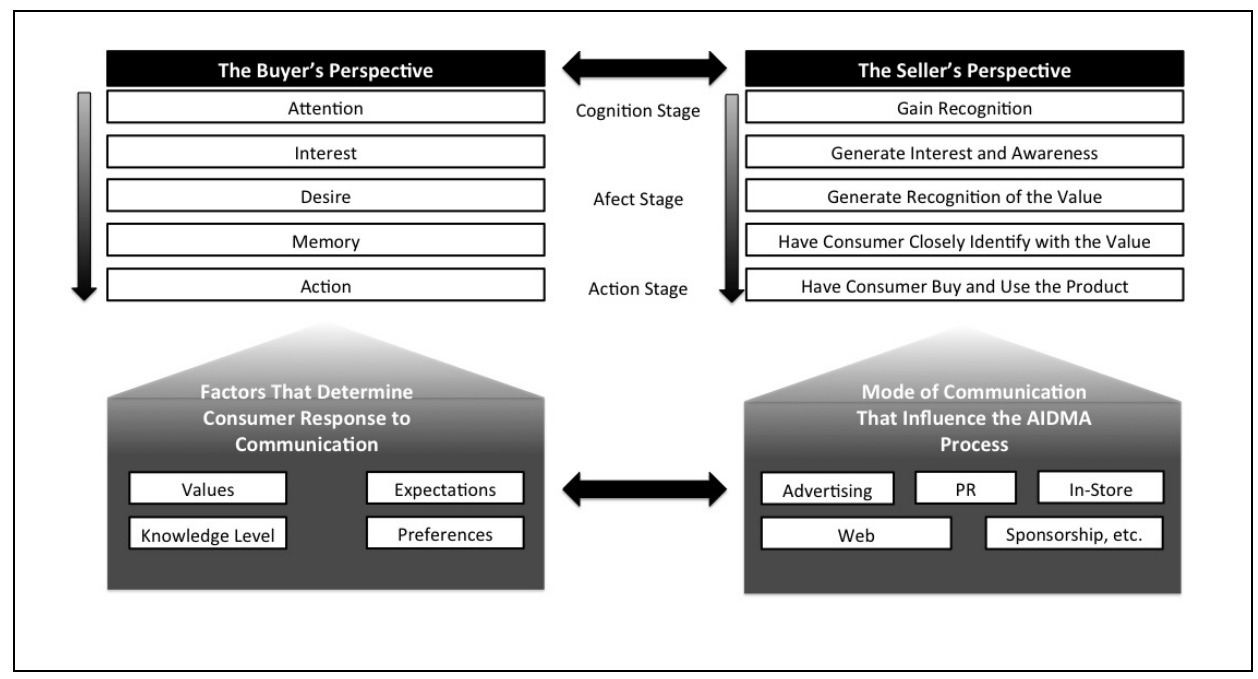

Fig. 13. AIDMA Law from the buyer's and the seller's perspective (adapted from Tanahashi 2011).

\subsubsection{First stage, attention: what is there that grabs the audience's attention?}

The consumer's attention on a particular advertisement mainly depends on three factors: a) the knowledge of a particular product, b) the interest of the consumer on that product and c) the consumer's level of awareness. For example, if a woman interested in the care of her skin is not aware that Vitamin $\mathrm{C}$ is good for her skin, when she comes across an advertisement that focuses on the richness of Vitamin $\mathrm{C}$ of a product, she may not pay attention to it. Thus, in order to draw the consumer's attention, sellers must tell their potential consumers how a particular product relates to their needs.

In the headlines previously analysed, sellers usually relate a particular product to a target audience by means of linguistic presupposition triggers (specially the possessive determiner your). Sometimes, this link between the product and the consumer is reinforced by providing supplementary information in the form of feature columns in the body copy of the ad, which explain how exactly a product may contribute to their well being, as represented in Figures 14 and 15.

\section{"Almost everyone in Europe gets insufficient vitamin D because the sun is not strong enough in winter to make any in the skin. People in Britain and Ireland have particularly low levels of the sunshine vitamin because of our cloudy summer climate......" Oliver Gillie, director of Health Research Forum.}

Fig. 14. Your daily dose of sunshine ... guaranteed. 


\section{"Most of us don't get enough vitamin D. \\ This is why I encourage my patients to have a simple blood test for deficiency. \\ New research shows that vitamin D \\ supports colon, breast and immune health \\ in addition to bone health. Supplements \\ are your best way to get vitamin $D$ as \\ opposed to the sun's damaging rays." \\ Dr. Frank J. Costa, MD \\ World renowned phvsician and health expert}

Fig. 15. Chances are, you're not getting enough vitamin D.

\subsubsection{Second Stage: Affect Stage: Interest, Desire and Memory}

When sellers try to draw the attention of their potential consumers, they frequently focus on the consumer's possible interests and desires. As previously seen, on many occasions, sellers presuppose audience's desires (greater muscles, a better body, to be faster, stronger and for longer, to burn more fat) in order to sell a particular product. Surprisingly enough is the fact that these desires may have been created at the very same moment the potential consumer enters in contact with the advertisement.

Apart from the use of presuppositions, the desire for a product may also be enhanced by presenting other ordinary customers' positive experiences about the product or by having a professional in the field demonstrating the validity of a product. In the previous examples, the signature of the health expert provides veracity to what is being stated at the same time that enhances the desire for the advertised product:
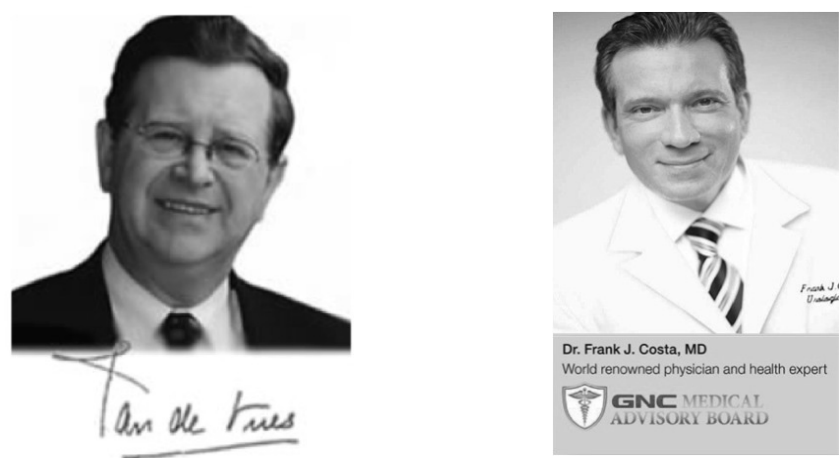

Fig. 16. Health experts. 


\subsubsection{The last stage: Action stage}

As the very same name indicates, this phase has to do with the actual process of buying the product and using it. Before consumers reach this stage, they may have to consult certain aspects related to the product, in this way, sellers do not usually hesitate to include in lower case letters different ways to contact them. If this information is not available, the risk for the sellers is that their potential customers may decide not to take action.

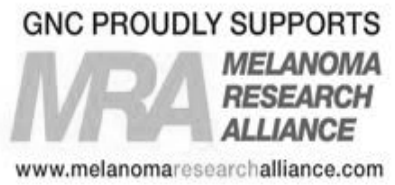

These statements have not been evaluated by the Food and Drug Administration. These products are not intended to diagnose, treat, cure or prevent any disease. Call 1.888 .462 .2548 or visit GNC.com for the store nearest you. $\odot 2010$ General Nutrition Corporation. May not be available outside the U.S. Ad: Arnell

Fig. 17. Contact information.

\section{CONCLUDING REMARKS}

At the beginning of this paper, it has been mentioned that presupposition fulfils two main functions in advertising (Tanaka 1996). However, it has been shown that not only is presupposition used "to make the reader forget that the speaker is trying to sell something", or to avoid taking responsibility for the social consequences of certain implications that may arise from advertisements (Tanaka, 1996: 44), but also to make the advertisement more effective by making it concise and polite.

Given that presupposition is a form of inferential information, this linguistic phenomenon clearly contributes to the conciseness of an advertisement (Lam, 2009: 53; Ge, 2011: 153). As exemplified in section 4.1, "utterances would be very uneconomic" without the use of presuppositions. Moreover, if an ad is short it would cost the advertiser less and it would also be more effective in terms of drawing the attention of the audience and helping them remember the product (section 4. 4. 3).

Presuppositions also fulfil a euphemistic function. In the language of advertising, it is sometimes necessary to remind the consumers the undesired state in which they are in order to sell a particular product that supposedly will change their situation for the better. However, this must be done subtly, in such a way that advertisers do not threaten the face of the consumers.

To conclude, presuppositions are a very slyly way of achieving persuasion in advertising and influencing consumer behaviour. The present study has demonstrated that the linguistic phenomenon of presupposition, in the more technical sense of the word, is triggered by a series of linguistic elements: from WH-questions to factive expressions. Although the findings show that comparative constructions, definite phrases and change-ofstate verbs are of special relevance in magazine food advertising, a larger corpus is needed in order to determine how far these results can be generalised. 


\section{REFERENCES (INCLUDING WEB SOURCES)}

ABEY, F. "The Components of an Advertisement". MBA Knowledge Base. 21 May 2012. http://www.mbaknol.com

Beaver, D. I. 1997. "Presupposition.” Handbook of Logic and Language. Eds. J. VAN Benthem and A. G. B. Ter Meulen. Amsterdam; Oxford: Elsevier. 1-57.

GE, L. 2011. "Pragmatic Functions of Presupposition in Advertising." Asian Culture and History 3: 153-157.

Goddard, A. 1998. The Language of Advertising: Written Texts. London: Routledge.

Grundy, P. 2008. Doing Pragmatics. 3rd ed. London: Hodder Education.

Hardin, K. 2001. Pragmatics in Persuasive Discourse of Spanish Television Advertising. Dallas, TX: SIL International; [Arlington, Tex.]: University of Texas at Arlington, Publications in Linguistics.

Karttunen, L., and S. Peters. 1979. Conventional implicature. Syntax and Semantics, Volume 11, Presupposition. Eds. CH. OH and D. A. DinneEn. New York: Academic Press. 1-56.

Katz, J. J., and T. Langendoen. 1976. "Pragmatics and Presupposition.” Language $52(1): 1-17$.

KIPARSKY, P. and KIPARSKY, C. 1971. "Fact.” Semantics: an Interdisciplinary Reader in Philosophy, Linguistics and Psychology. Eds. D. STEINBERG and L. JAKOBOvITS. Cambridge: Cambridge University Press. 345-369.

LAKOFF, R. 1982. "Persuasive discourse and ordinary conversation with examples from advertising." Analyzing discourse: Text and talk. Ed. D. TANNEN. Georgetown: Georgetown University Press. 25-42.

LAM, C. 2009. "What is useful about presupposition in advertisements and what does it reflect? A sociolinguistic study of Hong Kong culture." LCOM Papers 2: 45-55.

LEeCH, G. N. 1966. English in advertising: A linguistic study of advertising in Great Britain. London: Longman.

Levinson, S. C. 1983. Pragmatics. Cambridge: Cambridge University Press.

OxFord English Dictionary. 1884-1933. 10 vols. Eds. Sir James A. H. Murray, Henry Bradley, Sir William A. Craigie \& Charles T. Onions. Supplement, 1972-1986, 4 vols., ed. Robert Burchfield. 2nd edn. 1989, eds. John A. Simpson \& Edmund S. C. Weiner. Additions Series, 1993-1997, eds. John A. Simpson, Edmund S. C. Weiner \& Michael Proffitt. 3rd edn. in progress: OED Online, March 2000-, ed. John A. Simpson, www.oed.com.

PoP, A. 2010. "Implicatures derived through maxim flouting in print advertising: A contrastive empirical approach". Toronto Working Papers in Linguistics (TWPL) 3: $1-8$ 
SElls, P. and S. GonZÁLEz. 2002. "The Language of Advertising." Stanford University: Center for the Study of Language and Information. California. 21 May.2012. http:// www.stanford.edu/class/linguist34/index.htm

StalnaKer, R. C. 1972. "Pragmatics.” Semantics of natural language. Eds. D. DaVIDSON and G. HARMAN. Dordrecht: Reidel. 380-397.

—. 1974. "Pragmatic presuppositions." Semantics and philosophy. Eds. M. K. Munitz and P. K. Unger. New York: New York Press, 197-214.

Strawson, P. F. 1950. “On referring”. Mind 59: 320-44.

—. 1952. Introduction to Logical Theory. London: Methuen.

TanaHAShi, H. "Marketing Laws Applicable to Web Operations: The Aidma Law". Mitsue-Links. Japan. 21 May. 2012. http://www.mitsue.co.jp/english/

TANAKA, K. 1994. Advertising language: a pragmatic approach to advertisements in Britain and Japan. London: Routledge.

Yule, G. 1996. Pragmatics. Oxford: Oxford University Press.

WANG, Y. 2007. "Analysis of Presupposition and its Function in Advertisement." Canadian Social Science 3: 55-60

\section{APPENDIX I}

Health and Fitness (March 2012, UK. Target audience: women. Number of nutritional ads: 12 . Number of ads containing presuppositions: 7)

\section{CHANGE YOUR REFLECTION}

2. FASTER. STRONGER. FOR LONGER.

3. Whole food for your whole body

4. LITTLE BLACK DRESS? / NEW YEAR? / THAT BEACH BIKINI?

5. We take care of our omegas / you take care of your health

6. "The New Superfood Weight Loss Sensation" / The UK's Highest Strength \& Best Quality African Mango

7. Burn $41 \%$ More Fat During Exercise

Health and Fitness (April 2012, UK. Target audience: women. Number of nutritional ads: 9 . Number of repeated ads: 3 . Number of ads containing presuppositions: 3 )

8. Your daily dose of sunshine... guaranteed.

9. Get NOTICED! 
10. Do You Want To Know The Secrets Of Slimming?

Women's Health (January/February 2011, United States. Target audience: women. Number of nutritional ads: 10 . Number of ads containing presuppositions: 7)

11. As much protein as an egg. Does your cereal measure up?

12. $20 \%$ more calciyum / New Caltrate Soft Chews.

13. Best-in-Class Fish Oils

14. yes, Really

15. Chances are, you're not getting enough vitamin D

16. Definitely

17. The Fastest Growing Pre-Exercise Drink in America!

Men's Health (March 2012, UK. Target audience: men. Number of nutritional ads: 10. Number of repeated ads: 2. Number of ads containing presuppositions: 4)

18. THE TEAM BEHIND THE TEAM / maximuscle BEHIND YOUR PERFORMANCE

19. WHAT DRIVES YOU?

20. YOUR 12-WEEK NEW BODY STARTER PACK. The ultimate starter pack with the essential products to start your 12-week body transformation. Change your body and your lifestyle. It is possible. So the question is not 'if', but when you will start your transformation?

21. New Platinum Hydro Builder

Men's Health (April 2012, UK. Target audience: men. Number of nutritional ads: 11. Number of repeated ads: 7. Number of ads containing presuppositions: 4)

22. THE BEST JUST GOT BETTER

23. GREATER MUSCLE GAINS THAN ANY OTHER PRODUCT GUARANTEED. OR YOUR MONEY BACK.

\section{CHANGE / TO A SUPERIOR PROTEIN}

25. Probably the BEST muscle-gain shake in the world/ Maximum gains in muscle size \& strength - guaranteed. 


\section{APPENDIX II}

Health and Fitness (March 2012, UK. Target audience: women. Number of nutritional ads: 12 )

1. Reflex Diet Protein

- $\quad$ Sports supplement (diet protein shake)

- CHANGE YOUR REFLECTION (reflex / Tomorrow's Nutrition Today)

2. Lucozade Sport

- $\quad$ Sports drinks (Isotonic drink)

- $\quad$ FASTER. STRONGER. FOR LONGER. (Lucozade YES)

3. Forza's $T 5$

- $\quad$ Sports supplement

- How to look good naked. (Say hello to the new you. /DesirableBody / Look Good. Feel Great.)

4. Sun Chlorella 'A'

- Food supplement/dietary supplement (tablets)

- Whole food for your whole body.

5. nákd

- $\quad$ Nutritional product (chocolate bar)

- $\quad$ SHOCK / OLATE! (CHOCOLATEY \& GUILT FREE! / JUST FRUITS \& NUTS SMOOSHED TOGETHER / 1 OF 5 A DAY / NO ADDED SUGAR OR SYRUPS.)

6. Bio Synergy

- $\quad$ Food supplement (slimming aid, capsules)

- LITTLE BLACK DRESS? / NEW YEAR? / THAT BEACH BIKINI?

7. Omegas

- Food supplement

- We take care of our omegas / you take care of your health

8. New Vitabiotics Wellman Optimuscle

- $\quad$ Sports supplement (Vitamins supplement)

- Quite literally the making of champions / With under one year to go / Vitabiotics is set to astound the world of sport.

9. FLORADIX

- $\quad$ Food supplement (iron)

- $\quad$ tired of being tired? 
10. African Mango

- $\quad$ Food supplement

- PURE AFRICAN MANGO / "The New Superfood Weight Loss Sensation" / The UK's Highest Strength \& Best Quality African Mango

11. B-Slenda

- $\quad$ Food supplement (slimming aid)

- $\quad$ Goodbye FAT! (B-Slenda- A great tool for successful weight loss)

12. Low Calorie ZERO

- $\quad$ Sports drink

- Burn 41\% More Fat During Exercise

Health and Fitness (April 2012, UK. Target audience: women. Number of nutritional ads: 9 . Number of repeated ads: 3 )

1. Reflex Diet Protein

2. Maxitones's Sculptress Diet

- $\quad$ Sports supplement: shakes and bars

- (Say) Goodbye Festive Flab / Goodbye Christmas Treats / Hello Protein / Hello New You. (maxitone. The Body You Deserve)

3. Mornflake Organic Oats

- Organic product

- UPAND RUNNING.

4. DLUX 1000 Daily Vitamin D

- $\quad$ Food supplement (oral spray)

- Your daily dose of sunshine... guaranteed. (BetterYou just as nature intended. The sunshine vitamin.)

5. Sun Chlorella 'A'

6. Secrets of Slimming

- Dietary supplement (capsules)

- Do You Want To Know The Secrets Of Slimming?

7. Bio Synergy

- Dietary supplement

- IN TIME / MAKE EVERY SECOND COUNT WITH / BIO SYNERGY

8. Dietrim

- $\quad$ Dietary supplement (capsules) 
- Get NOTICED!

9. Low Calorie ZERO

Women's Health (January/February 2011, United States. Target audience: women. Number of nutritional ads: 10)

1. Emerald

- Cocoa roast almonds

- Where cocoa roAsted bliss meEts the goodness of ALMONDS. / AND ADDED CALORIES ARE GIVEN THE COLD SHOULDER.

2. Kashi GOLEAN cereals

- Nutritional product: cereals

- As much protein as an egg. Does your cereal measure up?

3. New Calftrate Soft Chews

- Calcium supplement

- $\quad \mathbf{2 0} \%$ more calciyum / New Caltrate Soft Chews. We put the yum in calcium.

4. Triple Strength Fish Oil

- Food supplement (tablets: heart, brain, joint, eye and skin health)

- Best-in-Class Fish Oils

5. BLUE DIAMOND

- Nutritional product (almonds)

- (It is/ it isn't) MORE THAN A SNACK IT'S A SUPERFOOD

6. WeightWatchers' Apple Pie a la Mode

- Nutritional product

- yes, Really

7. GNC MULTIVITAMINS

- Food supplement

- Chances are, you're not getting enough vitamin D / GNC LIVE WELL

8. WeightWatchers' Coffee Cake

- Nutritional product

- Definitely

9. CELSIUS

- $\quad$ Sports drink 
- CELSIUS / Your Ultimate Fitness Partner

- The Fastest Growing Pre-Exercise Drink in America!

10. Jimmy Deam D-lights

- Nutritional product (turkey sausage bowl)

- $\quad$-JUST 230 CALORIES- YOU COULD BURN THAT OFF TURNING THIS PAGE... A FEW HUNDRED TIMES / SHINE ON

Men's Health (March 2012, UK. Target audience: men. Number of nutritional ads: 10. Number of repeated ads: 2)

\section{Lucozade Sport}

2. Kikkoman

- Nutrition product (soy sauce)

- Good food tastes even better.

3. USN's PREMIUM 8 HR CASEIN

- $\quad$ Sports supplement (protein drink)

- PURPOSE DRIVEN PROTEIN / SLOW RELEASE.

4. maximuscle's Lean Definition

- $\quad$ Sports supplement (proteins and nutrients)

- THE TEAM BEHIND THE TEAM / maximuscle BEHIND YOUR PERFORMANCE

5. Predator Nutrition

- $\quad$ Sport supplements

- WHAT DRIVES YOU?

6. USN (ultimate sports nutrition). Body and Lifestyle challenge.

- Sports supplement pack

- YOUR 12-WEEK NEW BODY STARTER PACK. The ultimate starter pack with the essential products to start your 12-week body transformation. Change your body and your lifestyle. It is possible. So the question is not 'if', but when you will start your transformation?

7. MET-Rx. Shaping Every Body.

8. ON's New Platinum Hydro Builder

- $\quad$ Sports supplement

- Free amino energy with every purchase of ON's New Platinum Hydro Builder

9. New Vitabiotics Wellman Optimuscle 
10. SMART-TEC XcelR8

- $\quad$ Sports supplement (Vitamin and mineral stack)WARNING: Do not take two servings!/ The Ultimate Pre Workout Cell Voluminizing \& Focus Formula. Accelerate Your Training with SMART-TEC XcelR8

Men's Health (April 2012, UK. Target audience: men. Number of nutritional ads: 11. Number of repeated ads: 7. Number of ads containing presuppositions: 4.)

1. Lucozade Sport

2. Kikkoman

3. Maximuscle's MAXI-MILK

- $\quad$ Sports supplement (high protein shake)

- THE TEAM BEHIND THE TEAM / maximuscle BEHIND YOUR PERFORMANCE

4. PhD's Synergy-ISO-7

- $\quad$ Sports supplement (all-in-one sports nutrition product)

- THE BEST JUST GOT BETTER

5. SMART-TEC XcelR8

6. Predator Nutrition

7. ON's New Platinum Hydro Builder

- Sports supplement

- Free amino energy with every purchase of ON's New Platinum Hydro Builder /Only 180 calories

8. Sci-MX

- $\quad$ Sports supplement

- GREATER MUSCLE GAINS THAN ANY OTHER PRODUCT GUARANTEED. OR YOUR MONEY BACK. / Maximum gains in muscle size \& strength - guaranteed. / Let Sci-MX power you.

9. Reflex's Instant Whey

- $\quad$ Sports supplement

- CHANGE / TO A SUPERIOR PROTEIN

11. USN (ultimate sports nutrition). Body and Lifestyle challenge.

12. Sci-MX's OMNY-MX HARDCORE

- Sports supplement (muscle-building supplement)

- Probably the BEST muscle-gain shake in the world/ Maximum gains in muscle size \& strength - guaranteed. / Let Sci-MX power you. 


\section{Please use this identifier to cite or link to this item:}

ht tp://hdl. handle. net/10835/2075

Full metadata record

DC Field

Value

Language

dc.contributor.author Bouso, Tamara

dc.date.accessioned 2013-04-04T12: 10:35Z

dc.date.available 2013-04-04T12:10:35Z

dc.date.issued 2012

dc.identifier.issn 1578-3820

dc.identifier.uri http://hdl. handle.net/10835/2075

dc.description.abstract In this study presupposition is examined from es_ES the point of view of the type of information assumed by advertisers (Levinson 1983;

Goddard 1998) and the functions they ful fi I in achieving persuasion in nutritional

advertising. Thus, 25 headlines from 5 health

and fi tness magazines (2012) have been

classi fi ed according to the type of covert

information. The results indicate that there are

gender differences as regards this form of inferential information as well as the linguistic

items that trigger these presuppositions.

Whereas commercials addressed to men are more competitive, those addressed to women appeal more to their emotions.

dc.publisher Universidad de Almería.

es_ES

dc.source Odisea : Revista de Estudios Ingleses. Número es_ES

13, Enero-Diciembre 2012

dc.subject Technical presupposition

es_ES

dc.subject Ordinary presupposition

es_ES

dc.subject Covert information

es_ES

dc.subject Persuasion

es_ES

dc.subject Magazine food advertising

es_ES

dc.subject Gender differences

es_ES

dc.subject Linguistic presupposition-triggers

es_ES 


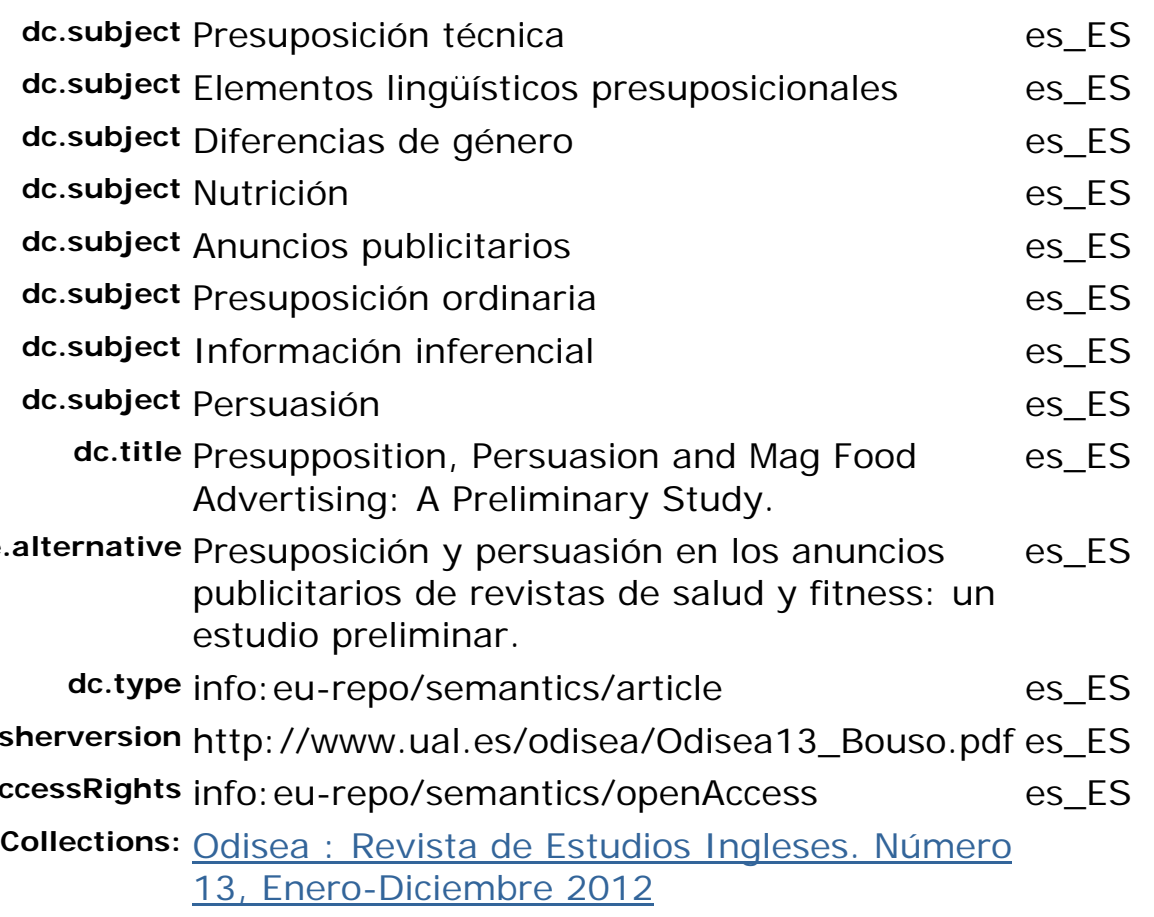

